Online Supporting Information for

\title{
Taking stock of built environment stock studies: Progress and prospects
}

Maud Lanau $^{\dagger}$, Gang Liu ${ }^{\dagger, *}$, Ulrich Kral ${ }^{\ddagger}$, Dominik Wiedenhofer ${ }^{\S}$, Elisabeth Keijzer ${ }^{\Perp}$, Chang Yu ${ }^{\perp}$, Christina Ehlert \#

† SDU Life Cycle Engineering, Department of Chemical Engineering, Biotechnology, and Environmental Technology, University of Southern Denmark, 5230 Odense, Denmark

$\ddagger$ Institute for Water Quality and Resource Management, Technische Universität Wien, 1040 Vienna, Austria

$\S$ Institute of Social Ecology, Department for Economics and Social Sciences, University of Natural Resources and Life Sciences, Vienna, 1090, Austria

II TNO Climate, Air and Sustainability, 3584 CB Utrecht, The Netherlands

$\perp$ School of Economics and Management, Beijing Forestry University, Beijing 100083, China

\# Luxembourg Institute of Science and Technology, 4422 Belvaux, Luxembourg

*Corresponding author: Gang Liu - Email: gli@kbm.sdu.dk; tel +45 65509441 
- Number of pages: 21

- Number of tables: 3

- Number of figures: 1

\section{Table of content}

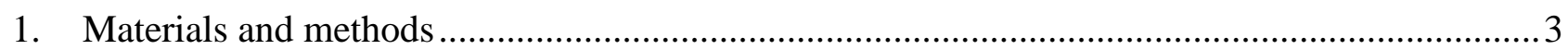

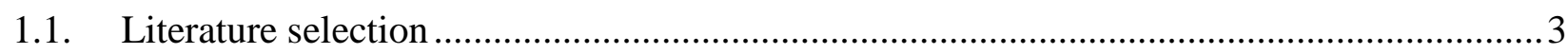

1.2. Reviewing process and development of the literature database ......................................

1.3. Data extraction, treatment, and comparison of results ....................................................

2. Complementary bibliometric analysis of the body of literature ............................................ 4

2.1. Number of publication by type and language over the body of literature........................... 4

2.2. Author frequency above three in the body of English literature ....................................... 4

2.3. Top 20 cited journal articles over the body of literature ...................................................5

2.4. Detailed frequency count on end-use in the body of literature ......................................... 7

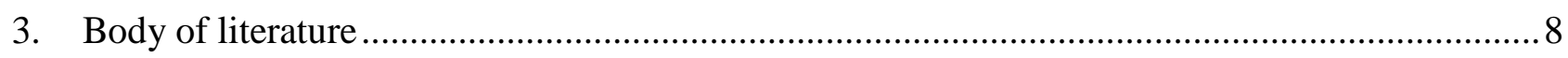

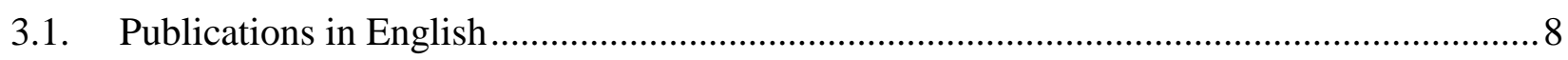

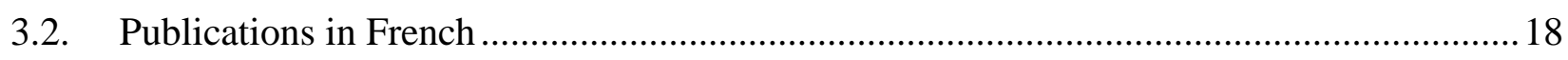

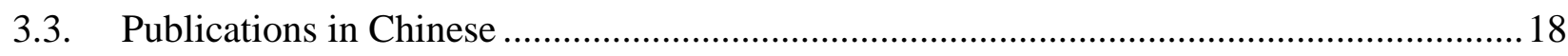

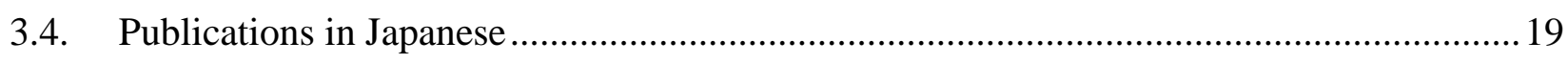

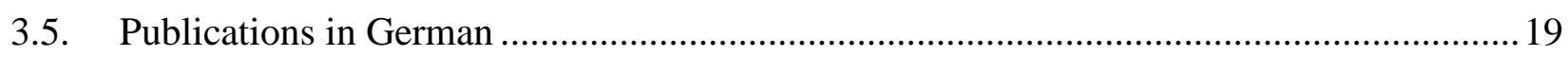




\section{Materials and methods}

\subsection{Literature selection}

Both Google Scholar and Web of Science were used to retrieve literature published in English. Combinations of keywords such as "stock", "material”, "in-use” were used. Reference lists of retrieved publications were screened for additional literature. Additionally, personal communication with experts in the field and internet searches allowed for retrieving of additional important papers published in German, French, Chinese, and Japanese. Grey literature such as reports prepared by academic institutions, industrial associations, governmental and non-governmental organizations, was explored as well.

\subsection{Reviewing process and development of the literature database}

A systematic reviewing process for manual screening of the literature was developed in order to review key characteristics of each study such as bibliometric data, scope, estimating approach, and purpose of study. More specifically, the following information were retrieved from each publication and are included in the body of literature database (Supporting Information S2):

- Bibliometrics

o Authors

o Year of publication

o Published in (e.g. name of scientific journal)

o Type of publication (Journal article; Conference article; PhD thesis; Master's thesis; Report; White paper)

o Language (English; French; German; Japanese; Chinese)

o Title

- $\quad$ Object of measurement

o Material(s) studied

o Unit(s) of measurement

o End-use sector as described in the publication

o End-use sector translated to the review terminology

o Status of stock (In-use; Hibernating; Total)

- Spatial scope

o Spatial boundary

o Location

o Spatial resolution

- Spatial Data collection (GIS; Remote Sensing; Other)

- $\quad$ Time scope

o Static/Dynamic

o Reference year

o Time scale

- Methodology (Bottom-up; Top-Down; Hybrid; Remote Sensing; Other) 


\subsection{Data extraction, treatment, and comparison of results}

We have collected empirical results of the studies that quantify the weight of the totality of construction material(s) in one or several parts of the built environment stock on the national or urban scales to allow for comparability or consistency check on a per-capita and per- $\mathrm{km}^{2}$ level. When the results were not directly measured on a per-capita or per- $\mathrm{km}^{2}$ level, population data of the year of study was retrieved from the United Nations Database.[1] The land areas data were retrieved from diverse sources such as the United Nations Database [1] or the National Bureau of Statistics (e.g., of China [2]). When the studies did not clearly define the urban area studied (e.g., city center or municipality), assumptions were made concerning boundaries of the urban system under focus, and related area and population.

[1] United Nations Statistics Division. UN Data http://data.un.org/

[2] National Bureau of Statistics of China. National Bureau of Statistics of China - Annual Data page http://www.stats.gov.cn/english/statisticaldata/AnnualData/

\section{Complementary bibliometric analysis of the body of literature}

\subsection{Number of publication by type and language over the body of literature}

Table S1 Number of publication by type and language over the body of literature

\begin{tabular}{|l|c|c|c|c|c|c|c|}
\cline { 2 - 8 } \multicolumn{1}{c|}{} & $\begin{array}{c}\text { Journal } \\
\text { article }\end{array}$ & $\begin{array}{c}\text { Conference } \\
\text { proceeding }\end{array}$ & $\begin{array}{c}\text { Master } \\
\text { thesis }\end{array}$ & $\begin{array}{c}\text { PhD } \\
\text { thesis }\end{array}$ & Report & $\begin{array}{c}\text { Working } \\
\text { Paper }\end{array}$ & Total \\
\hline English & 170 & 14 & 3 & - & 11 & 2 & 200 \\
\hline French & - & - & - & 2 & 2 & - & 4 \\
\hline Chinese & 1 & - & 2 & 1 & - & - & 4 \\
\hline Japanese & 4 & - & - & - & 2 & - & 6 \\
\hline German & 3 & - & 1 & 4 & 27 & - & 35 \\
\hline Total & 178 & 14 & 6 & 7 & 42 & 2 & 249 \\
\hline
\end{tabular}

\subsection{Author frequency above three in the body of English literature}

Table S2 Author frequency above three in the body of English literature

\begin{tabular}{|l|l|}
\hline Freq. & Author \\
\hline 23 & Müller, D.B. \\
\hline 18 & Tanikawa, H. \\
\hline 16 & Graedel, T.E. \\
\hline 15 & Brattebø, H. \\
\hline 14 & Matsuno, Y. \\
\hline 12 & Hashimoto, S. \\
\hline 9 & Adachi, Y. \\
\hline 9 & Sandberg, N.H. \\
\hline 9 & Wang, T. \\
\hline 8 & Daigo, I. \\
\hline 7 & Rauch, J.N. \\
\hline
\end{tabular}

\begin{tabular}{|l|l|}
\hline Freq. & Author \\
\hline 4 & Baccini, P. \\
\hline 4 & Chen, W.Q. \\
\hline 4 & Elvidge, C.D. \\
\hline 4 & Fellner, J. \\
\hline 4 & Han, J. \\
\hline 4 & Hsu, F.C. \\
\hline 4 & Kohler, N. \\
\hline 4 & Moriguchi, Y. \\
\hline 4 & Shi, F. \\
\hline 4 & Yuan, Z. \\
\hline 4 & Zhang, L. \\
\hline
\end{tabular}

\begin{tabular}{|l|l|}
\hline Freq. & Author \\
\hline 3 & Huppes, G. \\
\hline 3 & Kozawa, S. \\
\hline 3 & Krausmann, F. \\
\hline 3 & Krook, J. \\
\hline 3 & Lichtensteiger, T. \\
\hline 3 & Løvik, A.N. \\
\hline 3 & Lwin, C.M. \\
\hline 3 & Ortlepp, R. \\
\hline 3 & Passarini, F. \\
\hline 3 & Rechberger, H. \\
\hline 3 & Schiller, G. \\
\hline
\end{tabular}




\begin{tabular}{|l|l|}
\hline 6 & Bergsdal, H. \\
\hline 6 & Gordon, R.B. \\
\hline 6 & Liu, G. \\
\hline 6 & Pauliuk, S. \\
\hline 5 & Fishman, T. \\
\hline 5 & Sartori, I. \\
\hline 5 & Schandl, H. \\
\hline 5 & van Beers, D. \\
\hline 5 & van der Voet, E. \\
\hline
\end{tabular}

\begin{tabular}{|l|l|}
\hline 3 & Bader, H.P. \\
\hline 3 & Cai, Z. \\
\hline 3 & Cao, Z. \\
\hline 3 & Ciacci, L. \\
\hline 3 & Eckelman, M. \\
\hline 3 & Gruhler, K. \\
\hline 3 & Hassler, U. \\
\hline 3 & Hatayama, H. \\
\hline 3 & Hu, M. \\
\hline
\end{tabular}

\begin{tabular}{|l|l|}
\hline 3 & Shen, L. \\
\hline 3 & Tsukihashi, F. \\
\hline 3 & Vassura, I. \\
\hline 3 & Venkatesh, G. \\
\hline 3 & Wiedenhofer, D. \\
\hline 3 & Yang, J. \\
\hline 3 & Yue, Q. \\
\hline
\end{tabular}

\subsection{Top 20 cited journal articles over the body of literature}

Table S3 Top 20 cited journal articles over the body of literature

\begin{tabular}{|lc|}
\hline \multicolumn{1}{|c|}{ Article } & $\begin{array}{c}\text { Number of } \\
\text { citations }\end{array}$ \\
\hline $\begin{array}{l}\text { Müller, D.B., Stock dynamics for forecasting material flows - Case study for housing in the } \\
\text { Netherlands (2006) Ecological Economics, 59 (1), pp. 142-156 }\end{array}$ & 46 \\
\hline $\begin{array}{l}\text { Müller, D.B., Wang, T., Duval, B., Graedel, T.E., Exploring the engine of anthropogenic } \\
\text { iron cycles (2006) Proceedings of the National Academy of Sciences of the United States of } \\
\text { America, 103 (44), pp. 16111-16116 }\end{array}$ & 30 \\
\hline $\begin{array}{l}\text { Bergsdal, H., Bratteb?, H., Bohne, R.A., Müller, D.B., Dynamic material flow analysis for } \\
\text { Norway's dwelling stock (2007) Building Research \& Information, 35 (5), pp. 557-570 }\end{array}$ & 27 \\
\hline $\begin{array}{l}\text { Gordon, R.B., Bertram, M., Graedel, T.E., Metal stocks and sustainability (2006) } \\
\text { Proceedings of the National Academy of Sciences of the United States of America, 103 (5), } \\
\text { pp. 1209-1214 }\end{array}$ & 26 \\
\hline $\begin{array}{l}\text { Müller, D.B., Wang, T., Duval, B., Patterns of iron use in societal evolution (2010) } \\
\text { Environmental Science \& Technology, 45 (1), pp. 182-188 }\end{array}$ & 25 \\
\hline $\begin{array}{l}\text { Hatayama, H., Daigo, I., Matsuno, Y., Adachi, Y., Outlook of the world steel cycle based on } \\
\text { the stock and flow dynamics (2010) Environmental Science \& Technology, 44 (16), pp. }\end{array}$ & 22 \\
6457-6463 & \\
\hline $\begin{array}{l}\text { Hashimoto, S., Tanikawa, H., Moriguchi, Y., Where will large amounts of materials } \\
\text { accumulated within the economy go? - A material flow analysis of construction minerals for } \\
\text { Japan (2007) Waste Management, 27, pp. 1725-1738 }\end{array}$ & \\
\hline $\begin{array}{l}\text { Graedel, T.E., Beers van, D., Bertram, M., Fuse, K., Gordon, R.B., Gritsinin, A., Multi-level } \\
\text { cycle of anthropogenic copper (2004) Environmental Science \& Technology, 38, pp. 1242- } \\
\text { 1252 }\end{array}$ & 17 \\
\hline $\begin{array}{l}\text { Hashimoto, S., Tanikawa, H., Moriguchi, Y., Framework for estimating potential wastes } \\
\text { and secondary resources accumulated within an economy-A case study of construction } \\
\text { minerals in Japan (2009) Waste Management, 29 (11), pp. 2859-2866 }\end{array}$ \\
\hline $\begin{array}{l}\text { Kleijn, R., Huele, R., van der Voet, E., Dynamic substance flow analysis: the delaying } \\
\text { mechanism of stocks, with the case of PVC in Sweden (2000) Ecological Economics, 32 } \\
\text { (2), pp. 241-254 }\end{array}$ \\
\hline
\end{tabular}


Gerst, M.D., Linking material flow analysis and resource policy via future scenarios of in15 use stock: An example for copper (2009) Environmental Science and Technology, 43, pp. 6320-6325

Müller, E., Hilty, L.M., Widmer, R., Schluep, M., Faulstich, M., Modeling metal stocks and 13 flows: A review of dynamic material flow analysis methods (2014) Environmental Science \& Technology, 48 (4), pp. 2102-2113

Hu, M., Bergsdal, H., Van Der Voet, E., Huppes, G., Müller, D.B., Dynamics of urban and rural housing stocks in China (2010) Building Research \& Information, 38 (3), pp. 301-317 Tanikawa, H., Fishman, T., Okuoka, K., Sugimoto, K., The weight of society over time and space: a comprehensive account of the construction material stock of Japan, 1945-2010 (2015) J. Ind. Ecol., 19 (5), pp. 778-791

Pauliuk, S., Wang, T., Müller, D.B., Moving toward the circular economy: The role of stocks in the Chinese steel cycle (2012) Environmental Science \& Technology, 46 (1), pp. 148-154

Pauliuk, S., Wang, T., Müller, D.B., Steel all over the world: Estimating in-use stocks of iron for 200 countries (2013) Resources, Conservation and Recycling, 71, pp. 22-30

Daigo, I., Hashimoto, S., Matsuno, Y., Adachi, Y., Material stocks and flows accounting for 12 copper and copper-based alloys in Japan (2009) Resources Conservation and Recycling, 53, pp. 208-217

Bergsdal, H., Bohne, R.A., Bratteb?, H., Projection of construction and demolition waste in 12 Norway (2007) Journal of Industrial Ecology, 11 (3), pp. 27-39

Huang, T., Shi, F., Tanikawa, H., Fei, J., Han, J., Materials demand and environmental 11 impact of buildings construction and demolition in China based on dynamic material flow analysis (2013) Resources, Conservation and Recycling, 72, pp. 91-101

Daigo, I., Igarashi, Y., Matsuno, Y., Adachi, Y., Accounting for steel stock in Japan (2007) 10

ISIJ International, 47 (7), pp. 1065-1069 


\subsection{Detailed frequency count on end-use in the body of literature}

The number of case-studies focusing on each end-use is reported in the figure below, in which the end-use classification follows the classification developed for the tree (figure 1a in the article).

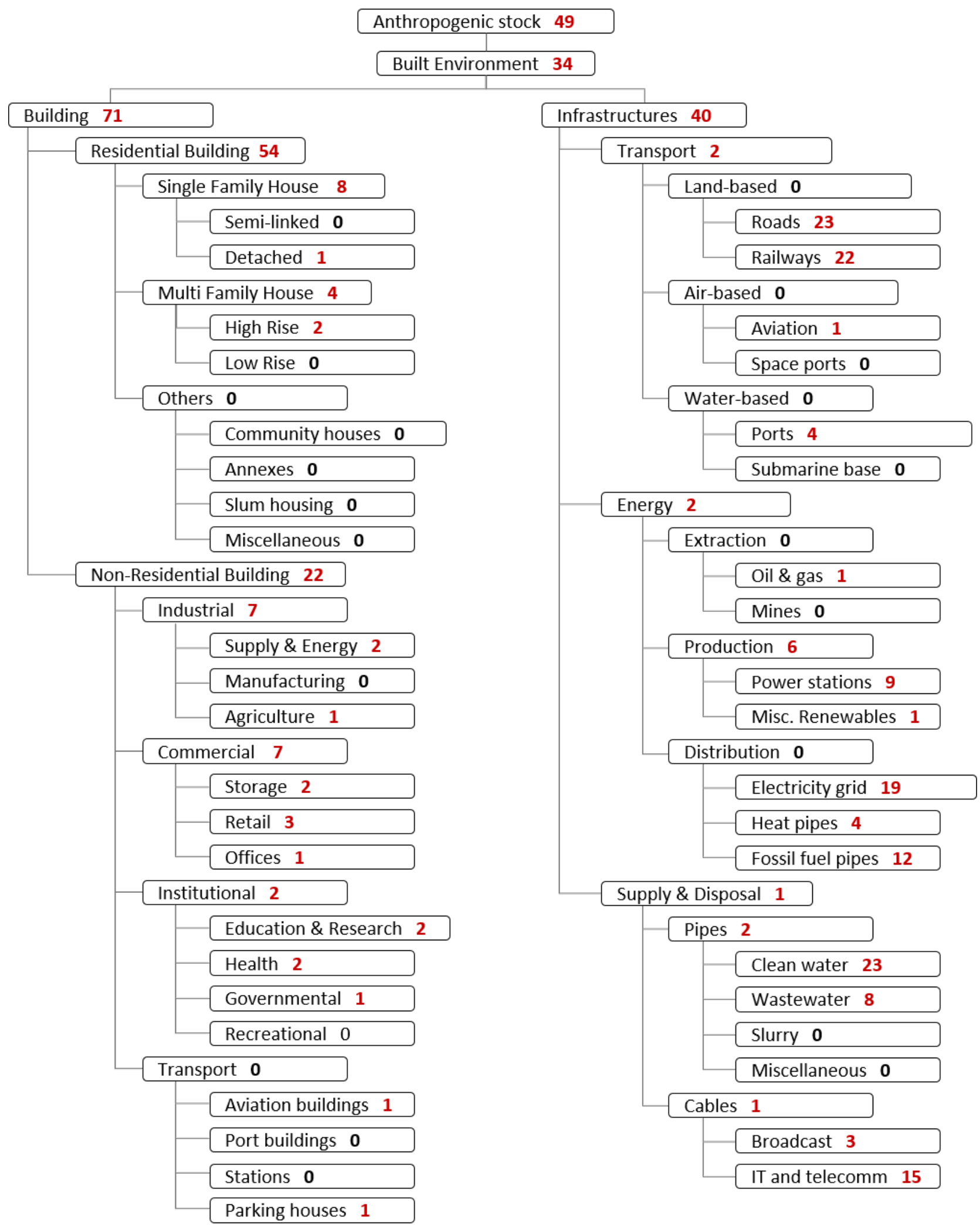

Figure S1 Number of article studying each end-use. 


\section{Body of literature}

The body of literature is composed of 249 publications in English, French, Chinese, Japanese or German. The reference list below is classified by language of publication.

\subsection{Publications in English}

Aksözen, M.; Hassler, U.; Kohler, N. Reconstitution of the Dynamics of an Urban Building Stock. Build. Res. Inf. 2016, 1-20.

Aksözen, M.; Hassler, U.; Rivallain, M.; Kohler, N. Mortality Analysis of an Urban Building Stock. Build. Res. Inf. 2016, 0 (0), 1-19.

Bader, H.-P.; Scheidegger, R.; Wittmer, D.; Lichtensteiger, T. Copper Flows in Buildings, Infrastructure and Mobiles: A Dynamic Model and Its Application to Switzerland. Clean Technol. Environ. Policy 2011, 13 (1), 87-101.

Baccini, P. Understanding Regional Metabolism for a Sustainable Development of Urban Systems. Environ. Sci. Pollut. Res. 1996.

Beers, D. Van; Berkel, R. van; Graedel, T. E.; van Beers, D.; Berkel, R. van; Graedel, T. E. The Application of Material Flow Analysis for the Evaluation of the Recovery Potential of Secondary Metals in Australia. Conference.Alcas.Asn.Au 1987, March 1 (February 2005), 1-14.

van Beers, D.; Graedel, T. E. The Magnitude and Spatial Distribution of In- Use Zinc Stocks in Cape Town, South Africa. African J. Environ. Assess. Manag. 2004, X (November), 1-19.

Belle, I.; Wang, T.; Hassler, U. Age of Land as Parameter for Sustainable Transformation of Singapore's Building Stock. Habitat Int. 2015, 48, 20-29.

Bellstedt, C. Material Flow Analysis for a Circular Economy Development, 2015, Vol. September.

Bergbäck, B.; Johansson, K.; Mohlander, U. Urban Metal Flows-A Case Study of Stockholm. Review and Conclusions. Water, Air, Soil Pollut. Focus 2001, 1, 3-24.

Bergsdal, H.; Brattebø, H.; Müller, D. B. Dynamic Material Flow Analysis for PCBs in the Norwegian Building Stock. Build. Res. Inf. 2014, 42 (3), 359-370.

Bergsdal, H.; Brattebø, H.; Bohne, R. A.; Müller, D. B. Dynamic Material Flow Analysis for Norway’s Dwelling Stock. Build. Res. Inf. 2007, 35 (5), 557-570.

Blomberg, J.; Söderholm, P. The Economics of Secondary Aluminium Supply: An Econometric Analysis Based on European Data. Resour. Conserv. Recycl. 2009, 53 (8), 455-463.

Bradley, P. E.; Kohler, N. Methodology for the Survival Analysis of Urban Building Stocks. Build. Res. Inf. 2007, 35 (5), 529-542.

Brattebø, H.; Bergsdal, H.; Sandberg, N. H.; Hammervold, J.; Müller, D. B. Exploring Built Environment Stock Metabolism and Sustainability by Systems Analysis Approaches. Build. Res. Inf. 2009, 37 (5-6), 569582.

Brown, F. E.; Rickaby, P. A.; Bruhns, H. R.; Steadman, P. Surveys of Nondomestic Buildings in Four English Towns. Environ. Plan. B Urban Anal. City Sci. 2000, 27 (1), 11-24.

Bruhns, H. R.; Steadman, P.; Herring, H.; Moss, S.; Rickaby, P. A. Types, Numbers, and Floor Areas of Nondomestic Premises in England and Wales, Classified by Activity. Environ. Plan. B Urban Anal. City Sci. 2000, 27 (5), 641-665.

Buchner, H.; Laner, D.; Rechberger, H.; Fellner, J. Dynamic Material Flow Modeling: An Effort to Calibrate and Validate Aluminum Stocks and Flows in Austria. Environ. Sci. Technol. 2015, 49 (9), 5546-5554. 
Cao, Z.; Shen, L.; Liu, L.; Zhao, J.; Zhong, S.; Kong, H.; Sun, Y. Estimating the In-Use Cement Stock in China: 1920-2013. Resour. Conserv. Recycl. 2017, 122, 21-31.

Cao, Z.; Shen, L.; Løvik, A. N.; Müller, D. B.; Liu, G. Elaborating the History of Our Cementing Societies: An in-Use Stock Perspective. Environ. Sci. Technol. 2017.

Cao, Z.; Shen, L.; Zhong, S.; Liu, L.; Kong, H.; Sun, Y. A Probabilistic Dynamic Material Flow Analysis Model for Chinese Urban Housing Stock. J. Ind. Ecol. 2017, 0 (0), 1-15.

Chen, C.; Shi, F.; Okuoka, K.; Tanikawa, H. The Metabolism Analysis of Urban Building by 4d-GIS - A Useful Method for New-Type Urbanization Planning in China. Univers. J. Mater. Sci. 2016, 4 (2), 40-46.

Chen, W. Q.; Graedel, T. E. Dynamic Analysis of Aluminum Stocks and Flows in the United States: 19002009. Ecol. Econ. 2012, 81, 92-102.

Chen, W. Q.; Shi, L. Analysis of Aluminum Stocks and Flows in Mainland China from 1950 to 2009:

Exploring the Dynamics Driving the Rapid Increase in China's Aluminum Production. Resour. Conserv.

Recycl. 2012, 65, 18-28.

Cheng, K. L.; Hsu, S. C.; Li, W. M.; Ma, H. W. Quantifying Potential Anthropogenic Resources of Buildings through Hot Spot Analysis. Resour. Conserv. Recycl. 2018, 133 (February), 10-20.

Christian, L.; Helmut, H.; Karl-Heinz, E.; Simone, G.; Fridolin, K. Global Socioeconomic Carbon Stocks in Long-Lived Products 1900-2008. Environ. Res. Lett. 2012, 7 (3), 34023.

Ciacci, L.; Passarini, F.; Vassura, I. The European PVC Cycle: In-Use Stock and Flows. Resour. Conserv. Recycl. 2017, 123, 108-116.

Ciacci, L.; Chen, W.; Passarini, F.; Eckelman, M.; Vassura, I.; Morselli, L. Historical Evolution of Anthropogenic Aluminum Stocks and Flows in Italy. Resour. Conserv. Recycl. 2013, 72, 1-8.

Ciacci, L.; Vassura, I.; Passarini, F. Urban Mines of Copper: Size and Potential for Recycling in the EU. Resources 2017, 6 (1), 6.

Condeixa, K.; Haddad, A.; Boer, D. Material Flow Analysis of the Residential Building Stock at the City of Rio de Janeiro. J. Clean. Prod. 2017, 149, 1249-1267.

Daigo, I.; Igarashi, Y.; Matsuno, Y.; Adachi, Y. Accounting for Steel Stock in Japan. ISIJ Int. 2007, 47 (7), 1065-1069.

Daigo, I.; Hashimoto, S.; Matsuno, Y.; Adachi, Y. Material Stocks and Flows Accounting for Copper and Copper-Based Alloys in Japan. Resour. Conserv. Recycl. 2009, 53 (4), 208-217.

Dall’O, G.; Galante, A.; Torri, M. A Methodology for the Energy Performance Classification of Residential Building Stock on an Urban Scale. Energy Build. 2012, 48, 211-219.

Daxbeck, H.; Buschmann, H.; Neumayer, S.; Brandt, B. Methodology for Mapping of Physical Stocks; 2009.

Deilmann, C.; Effenberger, K. H.; Banse, J. Housing Stock Shrinkage: Vacancy and Demolition Trends in Germany. Build. Res. Inf. 2009, 37 (5-6), 660-668.

Donovan, S.; Pickin, J. An Australian Stocks and Flows Model for Asbestos. Waste Manag. Res. 2016, $0734242 X 16659353$.

Drakonakis, K.; Rostkowski, K.; Rauch, J.; Graedel, T. E.; Gordon, R. B. Metal Capital Sustaining a North American City: Iron and Copper in New Haven, CT. Resour. Conserv. Recycl. 2007, 49 (4), 406-420.

EC Environmental Research Program 1994-1998. Materials Accounting as a Tool for Decision Making in Environmental Policy (MAc TEmPo); 1998. 
Eckelman, M. J.; Rauch, J.; Gordon, R. B. In-Use Stocks of Iron in the State of Connecticut, USA. Working Paper Number 11.; Yale School of Forestry \& Environmental Studies Publication Series; 11; 2007.

Elshkaki, A.; Van Der Voet, E.; Van Holderbeke, M.; Timmermans, V. The Environmental and Economic Consequences of the Developments of Lead Stocks in the Dutch Economic System. Resour. Conserv. Recycl. 2004, 42 (2), 133-154.

Elshkaki, A.; Graedel, T. E. Dynamic Analysis of the Global Metals Flows and Stocks in Electricity Generation Technologies. J. Clean. Prod. 2013, No. 0.

Ergun, D. The Potential Environmental Benefits of Reusable and Recyclable Materials Stocks in Toronto's Single-Detached Housing, 2014.

Ergun, D.; Gorgolewski, M. Inventorying Toronto's Single Detached Housing Stocks to Examine the Availability of Clay Brick for Urban Mining. Waste Manag. 2015, 45, 180-185.

European Aluminium Association and Organisation of European Aluminium Refiners and Remelters. Aluminium Recycling in Europe: The Road to High Quality Products; 2006.

Fishman, T.; Schandl, H.; Tanikawa, H. The Socio-Economic Drivers of Material Stock Accumulation in Japan's Prefectures. Ecol. Econ. 2015, 113, 76-84.

Fishman, T.; Schandl, H.; Tanikawa, H. Stochastic Analysis and Forecasts of the Patterns of Speed, Acceleration, and Levels of Material Stock Accumulation in Society. Environ. Sci. Technol. 2016, 50 (7), 3729-3737.

Fishman, T.; Schandl, H.; Tanikawa, H.; Walker, P.; Krausmann, F. Accounting for the Material Stock of Nations. J. Ind. Ecol. 2014, 18 (3), 407-420.

Fraanje, P. J. Use of Wood in New Dutch One Family Dwellings since 1969. Holz Als Roh-Und Werkst. 1999, 57 (6), 407-417.

Gallardo, C.; Sandberg, N. H.; Brattebø, H. Dynamic-MFA Examination of Chilean Housing Stock: LongTerm Changes and Earthquake Damage. Build. Res. Inf. 2014, 42 (3), 343-358.

Gerst, M. D. Linking Material Flow Analysis and Resource Policy via Future Scenarios of In-Use Stock: An Example for Copper. Environ. Sci. Technol. 2009, 43 (16), 6320-6325.

Glöser, S.; Soulier, M.; Tercero Espinoza, L. A. Dynamic Analysis of Global Copper Flows. Global Stocks, Postconsumer Material Flows, Recycling Indicators, and Uncertainty Evaluation. Environ. Sci. Technol. 2013, 47 (12), 6564-6572.

Glöser, S.; Soulier, M.; Espinoza, L. T.; Faulstich, M. Using Dynamic Stock \& Flow Models for Global and Regional Material and Substance Flow Analysis in the Field of Industrial Ecology: The Example of a Global Copper Flow Model. The 31st International Conference of the System Dynamics Society. Cambridge, Massachusetts USA 2013.

Gómez, F.; Guzmán, J. I.; Tilton, J. E. Copper Recycling and Scrap Availability. Resour. Policy 2007, 32 (4), 183-190.

Gontia, P.; Nägeli, C.; Rosado, L.; Kalmykova, Y.; Österbring, M. Material-Intensity Database of Residential Buildings: A Case-Study of Sweden in the International Context. Resour. Conserv. Recycl. 2018, 130 (November 2017), 228-239.

Gordon, R. B.; Bertram, M.; Graedel, T. E. Metal Stocks and Sustainability. Proc. Natl. Acad. Sci. 2006, 103 (5), 1209-1214.

Göswein, V.; Krones, J.; Celentano, G.; Fernández, J. E.; Habert, G. Embodied GHGs in a Fast Growing City: Looking at the Evolution of a Dwelling Stock Using Structural Element Breakdown and Policy Scenarios. J. Ind. Ecol. 2017, 00 (0). 
Gruhler, K.; Deilmann, C.; Hajek, P.; Tywoniak, J.; Lupisek, A.; Ruzicka, J.; Sojkova, K. Despite All Strategies for Enhancing Resource Efficiency, Per Capita Material Stock Is Increasing - Housing Stock and Building Material Flows in Germany 2050. In Cesb 10: Central Europe Towards Sustainable Building From Theory To Practice; 2010; pp 383-386.

Guo, Z.; Hu, D.; Zhang, F.; Huang, G.; Xiao, Q. An Integrated Material Metabolism Model for Stocks of Urban Road System in Beijing, China. Sci. Total Environ. 2014, 470-471, 883-894.

Guo, Z.; Shi, H.; Zhang, P.; Chi, Y.; Feng, A. Material Metabolism and Lifecycle Impact Assessment towards Sustainable Resource Management: A Case Study of the Highway Infrastructural System in Shandong Peninsula, China. J. Clean. Prod. 2017, 153, 195-208.

Han, J.; Xiang, W. N. Analysis of Material Stock Accumulation in China's Infrastructure and Its Regional Disparity. Sustain. Sci. 2013, 8 (4), 553-564.

Hashimoto, S.; Tanikawa, H.; Moriguchi, Y. Framework for Estimating Potential Wastes and Secondary Resources Accumulated within an Economy - A Case Study of Construction Minerals in Japan. Waste Manag. 2009, 29 (11), 2859-2866.

Hashimoto, S.; Tanikawa, H.; Moriguchi, Y. Where Will Large Amounts of Materials Accumulated within the Economy Go? - A Material Flow Analysis of Construction Minerals for Japan. Waste Manag. 2007, 27 (12), 1725-1738.

Hatayama, H.; Daigo, I.; Matsuno, Y.; Adachi, Y. Assessment of Recycling Potential of Aluminum in Japan, the United States, Europe and China. Nippon Kinzoku Gakkaishi/Journal Japan Inst. Met. 2008, 72 (10), 813-818.

Hatayama, H.; Daigo, I.; Matsuno, Y.; Adachi, Y. Outlook of the World Steel Cycle Based on the Stock and Flow Dynamics. Environ. Sci. Technol. 2010, 44 (16), 6457-6463.

Hatayama, H.; Tahara, K. Using Decomposition Analysis to Forecast Metal Usage in the Building Stock. Build. Res. Inf. 2014, 1-10.

Hattori, R.; Horie, S.; Hsu, F. C.; Elvidge, C. D.; Matsuno, Y. Estimation of In-Use Steel Stock for Civil Engineering and Building Using Nighttime Light Images. Resour. Conserv. Recycl. 2013.

Hedbrant, J. Stockhome: A Spreadsheet Model of Urban Heavy Metal Metabolism. Water, Air, Soil Pollut. Focus 2001, 1 (3), 55-66.

Heeren, N.; Hellweg, S. Tracking Construction Material over Space and Time: Prospective and GeoReferenced Modeling of Building Stocks and Construction Material Flows. J. Ind. Ecol. 2016, 00 (0).

Hirato, T.; Daigo, I.; Matsuno, Y.; Adachi, Y. In-Use Stock of Steel Estimated by Top-down Approach and Bottom-up Approach. J. Iron Steel Inst. Japan 2009, 49 (12), 1967-1971.

Höglmeier, K.; Weber-Blaschke, G.; Richter, K. Potentials for Cascading of Recovered Wood from Building Deconstruction-A Case Study for South-East Germany. Resour. Conserv. Recycl. 2017, 117, 304-314.

Hong, L.; Zhou, N.; Feng, W.; Khanna, N.; Fridley, D.; Zhao, Y.; Sandholt, K. Building Stock Dynamics and Its Impacts on Materials and Energy Demand in China. Energy Policy 2016, 94 (June 2015), 47-55.

Hou, W.; Tian, X.; Tanikawa, H. Greening China’s Wastewater Treatment Infrastructure in the Face of Rapid Development: Analysis Based on Material Stock and Flow through 2050. J. Ind. Ecol. 2015, 19 (1), 129-140.

Hsu, F.-C.; Daigo, I.; Matsuno, Y.; Adachi, Y. Estimation of Steel Stock in Building and Civil Construction by Satellite Images. ISIJ Int. 2011, 51 (2), 313-319.

Hsu, F.-C.; Elvidge, C. D.; Matsuno, Y. Exploring and Estimating In-Use Steel Stocks in Civil Engineering and Buildings from Night-Time Lights. Int. J. Remote Sens. 2013, 34 (2), 490-504. 
Hsu, F.-C.; Elvidge, C. D.; Matsuno, Y. Estimating In-Use Steel Stock of Civil Engineering and Building in China by Nighttime Light Image. Proc. Asia-Pacific Adv. Netw. 2011, 31, 59-69.

Hu, D.; You, F.; Zhao, Y.; Yuan, Y.; Liu, T.; Cao, A.; Wang, Z.; Zhang, J. Input, Stocks and Output Flows of Urban Residential Building System in Beijing City, China from 1949 to 2008. Resour. Conserv. Recycl. 2010, 54 (12), 1177-1188.

Hu, M.; Bergsdal, H.; van der Voet, E.; Huppes, G.; Müller, D. B. Dynamics of Urban and Rural Housing Stocks in China. Build. Res. Inf. 2010, 38 (3), 301-317.

Hu, M.; Pauliuk, S.; Wang, T.; Huppes, G.; van der Voet, E.; Müller, D. B. Iron and Steel in Chinese Residential Buildings: A Dynamic Analysis. Resour. Conserv. Recycl. 2010, 54 (9), 591-600.

Hu, M.; van der Voet, E.; Huppes, G. Dynamic Material Flow Analysis for Strategic Construction and Demolition Waste Management in Beijing. J. Ind. Ecol. 2010, 14 (3), 440-456.

Huang, C.; Han, J.; Chen, W. Q. Changing Patterns and Determinants of Infrastructures' Material Stocks in Chinese Cities. Resour. Conserv. Recycl. 2016.

Huang, T.; Shi, F.; Tanikawa, H.; Fei, J.; Han, J. Materials Demand and Environmental Impact of Buildings Construction and Demolition in China Based on Dynamic Material Flow Analysis. Resour. Conserv. Recycl. 2013, 72, 91-101.

International Aluminum Institute. Global Aluminium Recycling : A Cornerstone of Sustainable Development; 2009.

Jang, E.; Hong, S.-J.; Jung, J.-S.; Lee, J.-Y.; Hur, T. Analysis of Aluminum Flow and Stock in Korea. Life Cycle Assessment IX “toward the global life cycle economy.” Boston, US 2009.

Jolly, J. L. The U.S. Copper-Base Scrap Industry And Its By-Products - An Overview, 11th ed.; Copper Development Association Inc.: New York, 2011.

Kalcher, J.; Praxmarer, G.; Teischinger, A. Quantification of Future Availabilities of Recovered Wood from Austrian Residential Buildings. Resour. Conserv. Recycl. 2017.

Kandelaars, P. P. A. A. H.; van den Bergh, J. C. J. M. Dynamic Analysis of Materials-Product Chains: An Application to Window Frames. Ecol. Econ. 1997, 22 (1), 41-61.

Kapur, A.; Keoleian, G.; Kendall, A.; Kesler, S. E. Dynamic Modeling of In-Use Cement Stocks in the United States. J. Ind. Ecol. 2008, 12 (4), 539-556.

Kleemann, F.; Lederer, J.; Rechberger, H.; Fellner, J. GIS-Based Analysis of Vienna’s Material Stock in Buildings. J. Ind. Ecol. 2016, 00 (0), 1-13.

Kleijn, R.; Huele, R.; Van Der Voet, E. Dynamic Substance Flow Analysis: The Delaying Mechanism of Stocks, with the Case of PVC In Sweden. Ecol. Econ. 2000, 32 (2), 241-254.

Klinglmair, M.; Fellner, J. Historical Iron and Steel Recovery in Times of Raw Material Shortage: The Case of Austria during World War I. Ecol. Econ. 2011, 72 (0), 179-187.

Kloft, H.; Wörner, J.-D. Investigations of Mass and Energy Flow in Existing Buildings. In Durability of Building Materials and Components 8; Lacasse, M. A., Vanier, D. J., Eds.; National Research Council Canada 1999: Ottawa ON, K1A 0R6, Canada, 1999; pp 1426-1435.

Kloft, H.; Wörner, J.-D.; Liebermann, A. An Investigation of the Use of Building Materials in Residential Premises Constructed at Different Times. In IABSE congress report; 1996; pp 481-486.

Kozawa, S.; Tsukihashi, F. Analysis of Global Demand for Iron Source by Estimation of In-Use Steel Stock. ISIJ Int. 2011, 51 (2), 320-329. 
Kozawa, S.; Hayashi, S.; Tsukihashi, F. Analysis of Global Demand for Iron Source by Utility of Stock Hypothesis. ISIJ Int. 2008, 48 (12), 1795-1803.

Kozawa, S.; Tsukihashi, F. Prediction Model of Global Demand for Iron Source by Utility of Stock Hypothesis-Verification of Predictive Power and Outlook for Demand to 2050. ISIJ Int. 2010, 50 (10), 1503-1510.

Kral, U.; Lin, C. Y.; Kellner, K.; Ma, H. W.; Brunner, P. H. The Copper Balance of Cities: Exploratory Insights into a European and an Asian City. J. Ind. Ecol. 2014, 18 (3), 432-444.

Krausmann, F.; Wiedenhofer, D.; Lauk, C.; Haas, W.; Tanikawa, H.; Fishman, T.; Miatto, A.; Schandl, H.; Haberl, H. Global Socioeconomic Material Stocks Rise 23-Fold over the 20th Century and Require Half of Annual Resource Use, 2017, Vol. 114.

Krook, J.; Carlsson, A.; Eklund, M.; Frändegård, P.; Svensson, N. Urban Mining: Hibernating Copper Stocks in Local Power Grids. J. Clean. Prod. 2011, 19 (9-10), 1052-1056.

Laturi, J.; Mikkola, J.; Uusivuori, J. Carbon Reservoirs in Wood Products-in-Use in Finland: Current Sinks and Scenarios until 2050. Silva Fenn. 2008, 42 (2), 307-324.

Lederer, J.; Kleemann, F.; Ossberger, M.; Rechberger, H.; Fellner, J. Prospecting and Exploring Anthropogenic Resource Deposits: The Case Study of Vienna’s Subway Network. J. Ind. Ecol. 2016, 20 (6).

Li, L.; Wania, F. Tracking Chemicals in Products around the World: Introduction of a Dynamic Substance Flow Analysis Model and Application to PCBs. Environ. Int. 2016, 94, 674-686.

Liang, H.; Dong, L.; Tanikawa, H.; Zhang, N.; Gao, Z.; Luo, X. Feasibility of a New-Generation Nighttime Light Data for Estimating in-Use Steel Stock of Buildings and Civil Engineering Infrastructures. Resour. Conserv. Recycl. 2016, 1-13.

Liang, H.; Tanikawa, H.; Matsuno, Y.; Dong, L. Modeling In-Use Steel Stock in China’s Buildings and Civil Engineering Infrastructure Using Time-Series of DMSP/OLS Nighttime Lights. Remote Sens. 2014, 6 (6), 4780-4800.

Lichtensteiger, T.; Baccini, P. Exploration of Urban Stocks. J. Environ. Eng. Manag. 2008, 18 (1), 41-48.

Liu, G.; Müller, D. B. Centennial Evolution of Aluminum In-Use Stocks on Our Aluminized Planet. Environ. Sci. Technol. 2013, 47 (9), 4882-4888.

Liu, G.; Bangs, C. E.; Müller, D. B. Unearthing Potentials for Decarbonizing the U.S. Aluminum Cycle. Environ. Sci. Technol. 2011, 45 (22), 9515-9522.

Liu, G.; Bangs, C. E.; Müller, D. B. Stock Dynamics and Emission Pathways of the Global Aluminum Cycle. Nat. Clim. Chang. 2012, 2 (10), 178.

Lwin, C. M.; Dente, S. M. R. R.; Wang, T.; Shimizu, T.; Hashimoto, S. Material Stock Disparity and Factors Affecting Stocked Material Use Efficiency of Sewer Pipelines in Japan. Resour. Conserv. Recycl. 2016, 123, 135-142.

Mao, J.; Graedel, T. E. Lead In-Use Stock: A Dynamic Analysis. J. Ind. Ecol. 2009, 13 (1), 112-126.

Mao, R.; Duan, H.; Gao, H.; Wu, H. Characterizing the Generation and Management of a New Construction Waste in China: Glass Curtain Wall. Procedia Environ. Sci. 2016, 31, 204-210.

Marcellus-Zamora, K. A.; Gallagher, P. M.; Spatari, S.; Tanikawa, H. Estimating Materials Stocked by Land-Use Type in Historic Urban Buildings Using Spatio-Temporal Analytical Tools. J. Ind. Ecol. 2016, 20 (5), 1025-1037.

Mastrucci, A.; Marvuglia, A.; Popovici, E.; Leopold, U.; Benetto, E. Geospatial Characterization of Building Material Stocks for the Life Cycle Assessment of End-of-Life Scenarios at the Urban Scale. Resour.

Conserv. Recycl. 2016. 
Mata, É.; Sasic Kalagasidis, A.; Johnsson, F. Building-Stock Aggregation through Archetype Buildings: France, Germany, Spain and the UK. Build. Environ. 2014, 81, 270-282.

Maung, K. N.; Hashimoto, S.; Mizukami, M.; Morozumi, M.; Lwin, C. M. Assessment of the Secondary Copper Reserves of Nations. Environ. Sci. Technol. 2017, 51 (7), 3824-3832.

Maung, K. N.; Yoshida, T.; Liu, G.; Lwin, C. M.; Muller, D. B.; Hashimoto, S. Assessment of Secondary Aluminum Reserves of Nations. Resour. Conserv. Recycl. 2017, 126 (June), 34-41.

McMillan, C. A.; Moore, M. R.; Keoleian, G. A.; Bulkley, J. W. Quantifying U.S. Aluminum in-Use Stocks and Their Relationship with Economic Output. Ecol. Econ. 2010, 69 (12), 2606-2613.

Meinel, G.; Hecht, R.; Herold, H. Analyzing Building Stock Using Topographic Maps and GIS. Build. Res. Inf. 2009, 37 (February 2015), 468-482.

Mesta, C.; Kahhat, R.; Santa-Cruz, S. Geospatial Characterization of Material Stock in the Residential Sector of a Latin-American City. J. Ind. Ecol. 2018, 00 (0), 1-12.

Miatto, A.; Schandl, H.; Wiedenhofer, D.; Krausmann, F.; Tanikawa, H. Modeling Material Flows and Stocks of the Road Network in the United States 1905-2015. Resour. Conserv. Recycl. 2017.

Müller, D. B.; Wang, T.; Duval, B.; Graedel, T. E. Exploring the Engine of Anthropogenic Iron Cycles. Proc. Natl. Acad. Sci. 2006, 103 (44), 16111-16116.

Müller, D. B. Stock Dynamics for Forecasting Material Flows-Case Study for Housing in The Netherlands. Ecol. Econ. 2006, 59, 142-156.

Müller, D. B.; Wang, T.; Duval, B. Patterns of Iron Use in Societal Evolution. Environ. Sci. Technol. 2011, 45 (1), 182-188.

Müller, D. B.; Liu, G.; Løvik, A. N.; Modaresi, R.; Pauliuk, S.; Steinhoff, F. S.; Brattebø, H. Carbon Emissions of Infrastructure Development. Environ. Sci. Technol. 2013, 47 (20), 11739-11746.

Müller, D. B.; Bader, H.-P.; Baccini, P. Long-Term Coordination of Timber Production and Consumption Using a Dynamic Material and Energy Flow Analysis. J. Ind. Ecol. 2004, 8 (3), 65-88.

Murase, T.; Kawase, R.; Matsuoka, Y. Material Stock and Waste Generation by Human Activities Over the Past 100 Years. The Third World Congress of the Environmental and Resource Economists. Kyoto, Japan 2006.

Inc., N. A. The National Inventory of Obsolete Copper Scrap; 2004.

Neelis, M. L.; Patel, M. K. Long-Term Production, Energy Use and CO2 Emission Scenarios for the Worldwide Iron and Steel Industry; Innovation, C. I. for S. D. and, Ed.; Universiteit Utrecht, 2006.

Oda, J.; Akimoto, K.; Tomoda, T. Long-Term Global Availability of Steel Scrap. Resour. Conserv. Recycl. 2013, No. 0.

Oda, T.; Daigo, I.; Matsuno, Y.; Adachi, Y. Substance Flow and Stock of Chromium Associated with Cyclic Use of Steel in Japan. ISIJ Int. 2010, 50 (2), 314-323.

Olaya, Y.; Vásquez, F.; Müller, D. B. Dwelling Stock Dynamics for Addressing Housing Deficit. Resour. Conserv. Recycl. 2017, 123, 187-199.

Ortlepp, R.; Gruhler, K.; Schiller, G. Material Stocks in Germany’s Non-Domestic Buildings: A New Quantification Method. Build. Res. Inf. 2015, 3218 (April), 1-24.

Ortlepp, R.; Gruhler, K.; Schiller, G. Materials in Germany’s Domestic Building Stock: Calculation Model and Uncertainties. Build. Res. Inf. 2018. 
Panasiyk, D.; Laratte, B.; Remy, S. Steel Stock Analysis in Europe from 1945 to 2013. Procedia CIRP 2016, 48, 348-351.

Park, J. A.; Hong, S. J.; Kim, I.; Lee, J. Y.; Hur, T. Dynamic Material Flow Analysis of Steel Resources in Korea. Resour. Conserv. Recycl. 2011, 55 (4), 456-462.

Pauliuk, S.; Milford, R. L.; Müller, D. B.; Allwood, J. M. The Steel Scrap Age. Environ. Sci. Technol. 2013, 47 (7), 3448-3454.

Pauliuk, S.; Venkatesh, G.; Brattebø, H.; Müller, D. B. Exploring Urban Mines: Pipe Length and Material Stocks in Urban Water and Wastewater Networks. Urban Water J. 2014, 11 (4), 274-283.

Pauliuk, S.; Wang, T.; Müller, D. B. Moving toward the Circular Economy: The Role of Stocks in the Chinese Steel Cycle. Environ. Sci. Technol. 2012, 46 (1), 148-154.

Pauliuk, S.; Wang, T.; Müller, D. B. Steel All over the World: Estimating in-Use Stocks of Iron for 200 Countries. Resour. Conserv. Recycl. 2013, 71, 22-30.

Pingoud K.; Perälä, A. L. Studies on Greenhouse Impacts of Wood Construction: 1. Scenario Analysis of Potential Wood Utilisation in Finnish New Construction in 1990 and 1994 2. Inventory of Carbon Stock of Wood Products in the Finnish Building Stock in 1980, 1990 and 1995. VTT Julk. 2000, 840.

Quinn, D.; Fernandez, J. E. Estimating Material Usage of Road Infrastructure in US Cities. Fourth National Conference of IBPSA-USA, August 11 - 13, 2010. New York City, New York 2010.

Rauch, J. N.; Graedel, T. E. Earth’s Anthrobiogeochemical Copper Cycle. Global Biogeochem. Cycles 2007, $21(2), 1-13$.

Rauch, J.; Eckelman, M.; Gordon, R. Copper In-Use Stock and Copper Scrap in the State of Connecticut, USA; 2007.

Rauch, J. N. Global Mapping of Al, Cu, Fe, and Zn in-Use Stocks and in-Ground Resources. Proc. Natl. Acad. Sci. 2009, 106 (45), 18920-18925.

Rauch, J. N.; Pacyna, J. M. Earth’s Global Ag, Al, Cr, Cu, Fe, Ni, Pb, and Zn Cycles. Glob. Biogeochem. Cycles 2009, 23 (2), GB2001.

Recalde, K.; Wang, J.; Graedel, T. E. Aluminium In-Use Stocks in the State of Connecticut. Resour. Conserv. Recycl. 2008, 52 (11), 1271-1282.

Reyna, J. L.; Chester, M. V. The Growth of Urban Building Stock: Unintended Lock-in and Embedded Environmental Effects. J. Ind. Ecol. 2015, 19 (4), 524-537.

Richards, G. P.; Borough, C.; Evans, D.; Reddin, A.; Ximenes, F.; Gardner, D. Developing a Carbon Stocks and Flows Model for Australian Wood Products. Aust. For. 2007, 70 (2), 108-119.

Rostkowski, K.; Rauch, J.; Drakonakis, K.; Reck, B.; Gordon, R. B.; Graedel, T. E. “Bottom-up” Study of in-Use Nickel Stocks in New Haven, CT. Resour. Conserv. Recycl. 2007, 50 (1), 58-70.

Ruhrberg, M. Assessing the Recycling Efficiency of Copper from End-of-Life Products in Western Europe. Resour. Conserv. Recycl. 2006, 48 (2), 141-165.

Sandberg, N. H.; Bergsdal, H.; Brattebø, H. Historical Energy Analysis of the Norwegian Dwelling Stock. Build. Res. Inf. 2011, 39 (1), 1-15.

Sandberg, N. H.; Brattebø, H. Analysis of Energy and Carbon Flows in the Future Norwegian Dwelling Stock. Build. Res. Inf. 2012, 40 (2), 123-139.

Sandberg, N. H.; Sartori, I.; Brattebø, H. Using a Dynamic Segmented Model to Examine Future Renovation Activities in the Norwegian Dwelling Stock. Energy Build. 2014, 82, 287-295. 
Sandberg, N. H.; Sartori, I.; Heidrich, O.; Dawson, R.; Dascalaki, E.; Dimitriou, S.; Vimmr, T.; Filippidou, F.; Stegnar, G.; Sijanec Zavrl, M.; et al. Dynamic Building Stock Modelling: Application to 11 European Countries to Support the Energy Efficiency and Retrofit Ambitions of the EU. Energy Build. 2016, 132, 26 38.

Sandberg, N. H.; Sartori, I.; Vestrum, M. I.; Brattebø, H. Explaining the Historical Energy Use in Dwelling Stocks with a Segmented Dynamic Model: Case Study of Norway 1960 - 2015. Energy Build. 2016, 132, 141-153.

Sandberg, N. H.; Sartori, I.; Vestrum, M. I.; Brattebø, H. Using a Segmented Dynamic Dwelling Stock Model for Scenario Analysis of Future Energy Demand: The Dwelling Stock of Norway 2016-2050. Energy Build. 2017, 146, 220-232.

Sartori, I.; Bergsdal, H.; Muller, D. B.; Brattebø, H.; Müller, D. B.; Brattebø, H. Towards Modelling of Construction, Renovation and Demolition Activities: Norway’s Dwelling Stock, 1900-2100. Build. Res. Inf. 2008, 36 (5), 412-425.

Schebek, L.; Schnitzer, B.; Blesinger, D.; Köhn, A.; Miekley, B.; Linke, H. J.; Lohmann, A.; Motzko, C.; Seemann, A. Material Stocks of the Non-Residential Building Sector: The Case of the Rhine-Main Area. Resour. Conserv. Recycl. 2016, 1-13.

Schiller, G.; Müller, F.; Ortlepp, R. Mapping the Anthropogenic Stock in Germany: Metabolic Evidence for a Circular Economy. Resour. Conserv. Recycl. 2016.

Shi, F.; Huang, T.; Tanikawa, H.; Han, J.; Hashimoto, S.; Moriguchi, Y. Toward a Low CarbonDematerialization Society: Measuring the Materials Demand and Co 2 Emissions of Building and Transport Infrastructure Construction in China. J. Ind. Ecol. 2012, 16 (4), 493-505.

Sörme, L.; Bergbäck, B.; Lohm, U. CENTURY PERSPECTIVE OF HEAVY METAL USE IN URBAN AREAS A Case Study in Stockholm. Water, Air, Soil Pollut. Focus 2001, 1 (3-4), 197-211.

Spatari, S.; Bertram, M.; Gordon, R. B.; Henderson, K.; Graedel, T. E. Twentieth Century Copper Stocks and Flows in North America: A Dynamic Analysis. Ecol. Econ. 2005, 54 (1), 37-51.

Stephan, A.; Athanassiadis, A. Quantifying and Mapping Embodied Environmental Requirements of Urban Building Stocks. Build. Environ. 2017, 114, 187-202.

Sullivan, D. A. (USGS). Metal Stocks in Use in the United States; 2005.

Sundelin, K. E. Aluminium Recycling of the Norwegian Building Stock System, Norwegian University of Science and Technology: Trondheim, Norway, 2009.

Sundelin, K. E. Bottom-up Analysis of In-Use Stocks of Aluminium in Trondheim; Norwegian University of Science and Technology: Trondheim, Norway, 2008.

Surahman, U.; Higashi, O.; Kubota, T. Evaluation of Current Material Stock and Future Demolition Waste for Urban Residential Buildings in Jakarta and Bandung, Indonesia: Embodied Energy and CO2 Emission Analysis. J. Mater. Cycles Waste Manag. 2017, 19 (2), 657-675.

Takahashi, K. I.; Terakado, R.; Nakamura, J.; Adachi, Y.; Elvidge, C. D.; Matsuno, Y. In-Use Stock Analysis Using Satellite Nighttime Light Observation Data. Resour. Conserv. Recycl. 2010, 55 (2), 196-200.

Takahashi, K. I.; Terakado, R.; Nakamura, J.; Daigo, I.; Matsuno, Y.; Adachi, Y. In-Use Stock of Copper Analysis Using Satellite Nighttime Light Observation Data. Mater. Trans. 2009, 50 (7), 1871-1874.

Tanikawa, H.; Hashimoto, S. Urban Stock over Time: Spatial Material Stock Analysis Using 4d-GIS. Build. Res. Inf. 2009, 37 (5-6), 483-502. 
Tanikawa, H.; Fishman, T.; Okuoka, K.; Sugimoto, K. The Weight of Society over Time and Space: A Comprehensive Account of the Construction Material Stock of Japan, 1945-2010. J. Ind. Ecol. 2015, 19 (5), 778-791.

Tanikawa, H.; Hashimoto, S.; Moriguchi, Y. Estimation of Material Stock in Urban Civil Infrastructures and Buildings for the Prediction of Waste Generation. Proc. Fifth Int. Conf. Ecobalance, 6-8 Novemb. 2002 2002, 1-4.

Tukker, A.; Kleijn, R. .; van der Voet, E. . A Chlorine Balance for the Netherlands. Part II: Substance Documents; 1995.

van Beers, D.; Graedel, T. E. Spatial Characterisation of Multi-Level in-Use Copper and Zinc Stocks in Australia. J. Clean. Prod. 2007, 15 (8-9), 849-861.

van Beers, D.; Graedel, T. E. The Magnitude and Spatial Distribution of In-Use Copper in Cape Town. S. Afr. J. Sci. 2003, 99 (1/2), 61-74.

van Beers, D.; Kapur, A.; Graedel, T. E. Copper and Zinc Recycling in Australia: Potential Quantities and Policy Options. J. Clean. Prod. 2007, 15 (8-9), 862-877.

Vásquez, F.; Løvik, A. N.; Sandberg, N. H.; Müller, D. B. Dynamic Type-Cohort-Time Approach for the Analysis of Energy Reductions Strategies in the Building Stock. Energy Build. 2016, 111, 37-55.

Venkatesh, G.; Brattebø, H. Assessment of Environmental Impacts of an Aging and Stagnating Water Supply Pipeline Network: City of Oslo, 1991-2006. J. Ind. Ecol. 2012, 16 (5), $722-734$.

Venkatesh, G.; Hammervold, J.; Brattebø, H. Combined MFA-LCA for Analysis of Wastewater Pipeline Networks: Case Study of Oslo, Norway. J. Ind. Ecol. 2009, 13 (4), 532-550.

Wallsten, B.; Carlsson, A.; Frändegård, P.; Krook, J.; Svanström, S. To Prospect an Urban Mine - Assessing the Metal Recovery Potential of Infrastructure Cold Spots in Norrköping, Sweden. J. Clean. Prod. 2013, 55, 103-111.

Wallsten, B.; Magnusson, D.; Andersson, S.; Krook, J. The Economic Conditions for Urban Infrastructure Mining: Using GIS to Prospect Hibernating Copper Stocks. Resour. Conserv. Recycl. 2015, 103, 85-97.

Wang, J.; Graedel, T. E. Aluminum In-Use Stocks in China: A Bottom-up Study. J. Mater. Cycles Waste Manag. 2010, 12 (1), 66-82.

Wang, L.; Qi, Z.; Pan, F. Economic Output and Social Stock of Steel : Evidence from Dynamic Material Flow Analysis and Statistical Time Series Analysis. In 2014 International Conference on Management Science \& Engineering; Helsinki, Finland, 2014; pp 719-725.

Wang, P.; Li, W.; Kara, S. Cradle-to-Cradle Modeling of the Future Steel Flow in China. Resour. Conserv. Recycl. 2015.

Wang, T.; Tian, X.; Hashimoto, S.; Tanikawa, H. Concrete Transformation of Buildings in China and Implications for the Steel Cycle. Resour. Conserv. Recycl. 2014, 103, 205-215.

Wang, T.; Müller, D. B.; Hashimoto, S. The Ferrous Find Counting Iron and Steel Stocks in China's Economy. J. Ind. Ecol. 2015, 19 (5), 877-889.

Wang, T.; Shi, F.; Zhang, Q.; Qian, X.; Hashimoto, S. Exploring Material Stock Efficiency of Municipal Water and Sewage Infrastructures in China. J. Clean. Prod. 2018, 181, 498-507.

Wang, T.; Zhou, J.; Yue, Y.; Yang, J.; Hashimoto, S. Weight under Steel Wheels: Material Stock and Flow Analysis of High-Speed Rail in China. J. Ind. Ecol. 2016, 20 (6), 1349-1359.

Wen, Z.; Zhang, C.; Ji, X.; Xue, Y. Urban Mining’s Potential to Relieve China’s Coming Resource Crisis. J. Ind. Ecol. 2015, 19 (6), 1091-1102. 
Weng, C.-L.; Yashiro, T. Urban Mining: The City as a Source for Re-Usable Building Materials. 2003.

Wiedenhofer, D.; Steinberger, J. K.; Eisenmenger, N.; Haas, W. Maintenance and Expansion: Modeling Material Stocks and Flows for Residential Buildings and Transportation Networks in the EU25. J. Ind. Ecol. 2015, 19 (4), 538-551.

Wittmer, D.; Lichtensteiger, T. Exploration of Urban Deposits: Long-Term Prospects for Resource and Waste Management. Waste Manag. Res. 2007, 25 (3), 220-226.

Xuan, Y.; Yue, Q. Forecast of Steel Demand and the Availability of Depreciated Steel Scrap in China. Resour. Conserv. Recycl. 2016, 109, 1-12.

Yang, W.; Kohler, N. Simulation of the Evolution of the Chinese Building and Infrastructure Stock. Build. Res. Inf. 2008, 36 (March 2015), 1-19.

Yin, X.; Chen, W. Trends and Development of Steel Demand in China: A Bottom-up Analysis. Resour. Policy 2013, 38 (4), 407-415.

Yue, Q.; Wang, H. M.; Lu, Z. W. Quantitative Estimation of Social Stock for Metals Al and Cu in China. Trans. Nonferrous Met. Soc. China (English Ed. 2012, 22 (7), 1744-1752.

Yue, Q.; Wang, H.; Gao, C.; Du, T.; Li, M.; Lu, Z. Analysis of Iron In-Use Stocks in China. Resour. Policy 2016, 49, 315-322.

Zeltner, C.; Bader, H. P.; Scheidegger, R.; Baccini, P. Sustainable Metal Management Exemplified by Copper in the USA. Reg. Environ. Chang. 1999, 1 (1), 31-46.

Zhang, L.; Cai, Z.; Yang, J.; Chen, Y.; Yuan, Z. Quantification and Spatial Characterization of In-Use Copper Stocks in Shanghai. Resour. Conserv. Recycl. 2014, 93, 134-143.

Zhang, L.; Cai, Z.; Yang, J.; Yuan, Z.; Chen, Y. The Future of Copper in China-A Perspective Based on Analysis of Copper Flows and Stocks. Sci. Total Environ. 2015, 536, 142-149.

Zhang, L.; Yang, J.; Cai, Z.; Yuan, Z. Understanding the Spatial and Temporal Patterns of Copper In-Use Stocks in China. Environ. Sci. Technol. 2015, 49 (11), 6430-6437.

Zhang, L.; Yuan, Z.; Bi, J. Estimation of Copper In-Use Stocks in Nanjing, China. J. Ind. Ecol. 2012, 16 (2), 191-202.

\subsection{Publications in French}

Augiseau, V. La Dimension Matérielle de l'urbanisation - Flux et Stocks de Matériaux de Construction En Ile-de-France, Université Paris 1 Panthéon-Sorbonne, 2017.

Faist Emmenegger, M.; Frischknecht, R.; Cornaglia, L.; Rubli, S. Métabolisme Des Activités Économiques Du Canton de Genève - Phase 1. SubStance 2003, 41 (0), 106.

Gobbo, É. Déchets De Construction, Matières à Conception Analyse Des Stocks et Flux de Matières Dans Le Cadre Des Opérations de Rénovation Énergétique En Région de Bruxelles-Capitale, Université catholique de Louvain, 2015.

Rouvreau, L.; Michel, P.; Serrand, M.; Montfort-Climent, D.; Jayr, E.; Papinot, P.-E. Rapport Final Du Projet ANR ASURET : Analyse de Flux de Matière Du Secteur de La Construction à l'échelle de l'ouvrage et Du Territoire. 2012, 132.

\subsection{Publications in Chinese}

Kun, Y. "Study on the Evolution of Chinese Provincial Construction Stock and Its Influence on Material and Energy Demand” (In Chinese), 2017.

Lou, Y.; Shi, L. Analyzing Iron and Aluminum Stocks in Handan City in 2005 (in Chinese). Resour. Sci. 2008, 30 (1), 147-152. 
Wei, Y. "Modeling the Evolution of Chineses Building Stock in a Sustainable Perspective” (in Chinese), 2006.

Yu, L. "Material Metabolism for Cities: Methodology and Case Study of Handan City” (in Chinese), 2007.

\subsection{Publications in Japanese}

Science and Technology Agency Tokyo; Government of Japan. Study for Steel Stock in Japan (in Japanese); 1985.

Japan Ferrous Raw Material Association. Volume 1 (in Japanese); 1999.

Terakado, R.; Ichino Takahashi, K.; Daigo, I.; Matsuno, Y.; Adachi, Y. Estimation of In-Use Stock of Copper in China, Korea and Taiwan (in Japanese). J. Japan Inst. Met. 2009, 73 (11), 833-838.

Terakado, R.; Takahashi, K. I.; Daigo, I.; Matsuno, Y.; Adachi, Y. In-Use Stock of Copper in Japan Estimated by Bottom-Up Approach (in Japanese). J. Japan Inst. Met. Mater. 2009, 73 (9), 713-719.

Shimomura, Y.; Hayashi, S. Title Unknown (in Japanese). Bull. Iron Steel Inst. Japan 2005.

Taguchi, G.; Hsu, F.-C.; Tanikawa, H.; Matsuno, Y. Estimation of Steel Use in Buildings by Night Time Light Image and GIS. Tetsu-to-Hagane (Journal Iron Steel Inst. Japan) 2012, 98 (8), 450-456

\subsection{Publications in German}

Arendt, M. Kreislaufwirtschaft Im Baubereich: Steuerung Zukünftiger Stoffströme Am Beispiel von Gips, 2000.

Bergmann, T.; Bleher, D.; Jenseit, W. Ressourceneffizienzpotenziale Im Tiefbau. Materialaufwendungen Und Technische Lösungen Im Tiefbau; 2015.

Buchert, M.; Fritsche, U.; Jenseit, W.; Rausch, L.; Deilmann, C.; Schiller, G.; Siedentop, S.; Lipkow, A. Nachhaltiges Bauen und Wohnen in Deutschland. Stoffflussbezogene Bausteine für ein nationales Konzept der nachhaltigen Entwicklung - Verknüpfung des Bereiches Bauen und Wohnen mit dem komplementären Bereich „Öffentliche Infrastruktur“; 2004.

Daxbeck, H.; Stockinger, M.; Brandt, B. Beitrag Der Abfallwirtschaft Zum Kupferhaushalt Österreich; 2006.

Daxbeck, H.; Schönbauer, A.; Brunner, P. H. Machbarkeitsstudie Nationale Stoffbuchhaltung: Testbeispiel Zink.; 1998.

Daxbeck, H.; Lampert, C.; Obernosterer, R.; Rechberger, H.; Reiner, I.; Brunner, P. H. Der Anthropogene Stoffhaushalt Der Stadt Wien - N, C Und Pb (Projekt PILOT); 1996.

Daxbeck, H.; Reisenberger, M.; Kampel, E. Güterhaushalt Österreich (Projekt ABASG II); 2003.

Deilmann, C.; Kraus, N.; Gruhler, K. Sensitivitätsstudie Zum Kreislaufwirtschaftspotenzial Im Hochbau; 2014.

Deilmann, C.; Gruhler, K. Stoff- Und Energieflüsse von Gebäuden Und Infrastrukturen Als Grundlage Für Ein Vorausschauendes Szenariogeleitetes Stoffstrommanagement. Österreichische Wasser- und Abfallwirtschaft 2005.

Fehringer, R.; Brunner, P. H.; Baumann, H. Kunststoffflüsse Und Möglichkeiten Der Kunstoffverwendung in Österreich; 1997.

Gamsjäger, M. Ressourcenpotential Städtischer Verkehrsinfrastruktur Am Beispiel Der Wiener U-Bahn, 2015.

Gauch, M.; Mastraci, C.; Hincapie, I.; Hörler, R.; Böni, H. Material- Und Energieressourcen Der Baulichen Infrastruktur Der Schweiz; 2016. 
Glenck, E.; Lahner, T.; Jereb, W.; Leitner, E. Bauwesen - Abfallstrategien in Der Steiermark: Lageraufbau Im Bauwesen (Projekt LAUF); 2000.

Hintemann, R.; Fichter, K. Materialbestand Der Rechenzentren in Deutschland; 2010.

Hofer, P.; Taverna, R.; Werner, F.; Kaufmann, E.; Thürig, E. CO2-Effekte Der Schweizer Wald- Und Holzwirtschaft.; 2007.

Kleemann, F.; Lederer, J.; Fellner, J. Hochbauten Als Wertstoffquelle; 2015.

Kral, U.; Allesch, A.; Helmut, R. Der Städtische Untergrund Als Rohstoffmine? Potential an

Sekundärressourcen in Der Erdverlegten Infrastruktur. [The Urban Underground as Mine? Potential of Secondary Resources in Underground Networks.].

Lederer, J.; Kral, U.; Brunner, P. H. Vom Ökologischen Fußabdruck Zum Ressourcen- Und Umweltmanagement Am Beispiel Der Wiener Linien (ÖFRU). Arbeitspaket 1: Ökologischer Fußabdruck Der U2 Verlängerung; 2010.

Merl, A. D. Ressourcenmanagement in Urbanen Räumen : Fallstudie Wien Nachhaltiger Einsatz von Holz Im Rohbau, 2005.

Müller, D. B. Modellierung, Simulation Und Bewertung Des Regionalen Holzhaushaltes, 1998.

Obernosterer, R.; Smutny, R.; Jäger, E. Nachhaltige FCKW Bewirtschaftung Österreich. [Sustainable CFC Management in Austria.]; 2005.

Ortlepp, R.; Gruhler, K.; Schiller, G.; Ortlepp, S. Grundlagen Für Materialeffizientes Planen Und Bauen. Bautechnik 2017, 94 (1), 10-18.

Ott, C.; Kral, U.; Brunner, P. H. Vom Ökologischen Fußabdruck Zum Ressourcen- Und Umweltmanagement Am Beispiel Der Wiener Linien (ÖFRU). Arbeitspaket 2: Ressourcen- Und Umweltbezogene Wissensbasis Für Die Wiener Linien; 2012.

Redle, M. Kies- Und Energiehaushalt Urbaner Regionen in Abhängigkeit Der Siedlungsentwicklung, 1999.

Redle, M.; Baccini, P. Stadt Mit Wenig Energie, Viel Kies Und Neuer Identität. Metabolische Modelle Für Den Umbau Urbaner Siedlungen Am Beispiel Der Wohngebäude. Gaia 1998.

Rubli, S.; Wagner, R.; Kuhn, E.; Eugster, M.; Marugg, D.; Bürzle, S. Dynamische Modellierung Der Asphalt- Sowie PAK-Lager Und Flüsse in Den Strassen Der Region St. Gallen, Thurgau, Zürich Und Fürstentum Liechtenstein; 2013.

Rubli, S. Bauabfälle in Der Schweiz - Tiefbau; 2016.

Scharp, M. Materialbestand Und Materialflüsse Der IuK - Infrastrukturen: Mobilfunk; 2011.

Schneider, M.; Rubli, S. Dynamische Stoffflussanalyse Der Mineralischen Baustoffe Der Stadt Zürich 19952050; 2009.

Schneider, M.; Rubli, S. Ressourcenmodell Mineralischer Baustoffe Auf Der Ebene Stadt Zürich; 2007.

Schöller, G.; Oberleitner, C.; Fehringer, R.; Döberl, G.; Brunner, P. H. Verknüpfung Rohstofflager Anthropogene Lager - Letzte Senken; 2006.

Stark, W.; Vogel-Lahner, T.; Frühwirth, W. Bauwerk Österreich - Management von Baurestmassen Nach Den Gesichtspunkten Der Optimalen Ressourcennutzung Und Des Langfristigen Umweltschutzes Anhand Der Güter- Und Stoffbilanz Des „Bauwerks Österreich“; 2003.

Steger, S.; Fekkak, M.; Bringezu, S. Materialbestand Und Materialflüsse in Infrastrukturen [Material Stock and Material Flow in Infrastructure]; 2011.

Wüest \& Partner AG. Bauabfälle Hochbau in Der Schweiz. Ergebnisse Der Studie 2008.; 2008. 
Wüest \& Partner AG. Bauabfälle in Der Schweiz - Hochbau Studie 2015; 2015 